Original article

\title{
Evaluation of Proline, Chlorophyll, and Carotenoid Contents of Two Globe Artichokes [Cynara cardunculus var. scolymus (L.) Fiori] Leaves Based on the Growing Season
}

\author{
Tuğçe Özsan Kılıç (D) a," ${ }^{\text {a }}$ Timur Tongur (1) b \& Ahmet Naci Onus (i) a \\ a Department of Horticulture, Faculty of Agriculture, Akdeniz University, Antalya, Turkey \\ ${ }^{b}$ Department of Chemistry, Faculty of Science, Akdeniz University, Antalya, Turkey
}

\begin{abstract}
Globe artichoke [Cynara cardunculus var. scolymus (L.) Fiori], a member of the Asteraceae family, has been known since ancient times. Edible parts of this valuable vegetable are rich in antioxidants and polyphenols as well as possessing healing properties against certain diseases. When the life cycle of plants is taken into consideration, the processes which are highly affected by environmental conditions are photosynthesis and cell growth. Chlorophyll level is known as a good indicator of the photosynthesis of plants. Carotenoids, one of the important functions of which protects chlorophyll from photo-oxidation, can prevent the destruction of chlorophyll. Therefore, chlorophyll and carotenoids play an important role in photosynthesis and the protection of photosynthetic pathways against harmful free radicals. The proline concentration present in various plants is increased in many different stress conditions, such as cold, temperature, salinity, drought, UV, and heavy metals, thus, providing better tolerance to stress conditions. The aim of the present study was to comparatively evaluate the proline, chlorophyll ( $a$ and $b$ ), and carotenoid contents of the young and mature leaves of two OP cultivars (Bayrampaşa and Sakız) based on different growing seasons. Obtained results demonstrated that there were differences between two OP artichoke cultivars based on the growing season and young and mature leaves with regards to proline, chlorophyll ( $a$ and $b$ ), and carotenoid contents. Findings revealed that proline and chlorophyll b levels in autumn were quite promising, while in terms of chlorophyll a and carotenoid levels winter was prominent. Regarding the young and mature leaves, high proline and chlorophyll a levels were found to be dominant in young leaves. On the other hand, chlorophyll $b$ and carotenoid were more accumulated in mature leaves. Turkey has several other globe artichoke cultivars and the findings of the present study may play a supportive role in determining proline, chlorophyll (a and b), and carotenoid contents for combating several environmental stress factors.
\end{abstract}

Keywords: Artichoke, Carotenoid, Chlorophyll, Proline.

Received: 13 October 2021 * Accepted: 11 November $2021 \quad * \quad$ Dol: https://doi.org/10.29329/ijiasr.2021.414.2

\footnotetext{
* Corresponding author:

Onus, Ahmet Naci C is a professor in the Department of Horticulture at Akdeniz University in Antalya, Turkey. His research interests include the Agricultural Sciences, Vegetable Breeding and Breeding, Biotechnology and Genetics. He has lived, worked, and studied in Antalya, Turkey. Email: onus@akdeniz.edu.tr
} 


\section{INTRODUCTION}

Globe artichoke [Cynara cardunculus var. scolymus (L.) Fiori] is a perennial plant of Asteraceae family. It is widely cultivated for its capitula in the Mediterranean region (Fratianni et al., 2007). Although globe artichoke leaves are seen as crop residue because these are uneaten parts, they have had many beneficial effects on human health and are known and widely used as herbal medicine since ancient ages (Gebhardt, 2001; Lombardo et al., 2010; Pandino et al., 2013). Globe artichoke leaves can be utilized for treatments of some chronic disorders thanks to their therapeutic properties related to antioxidant, anti-fungal, anti-bacterial, and hepatoprotective effects (Romani et al., 2006; Lattanzio et al., 2009; Vamanu et al., 2011; Ruiz-Aceituno et al., 2016).

Plants' chemical properties are affected by various factors, such as geographic position, climate condition, genetics, genotype differences, and agricultural practices (Siadat-Jamian et al., 2019). Plants are needed to the convenient environmental conditions, in order to maintain their normal development. On the other hand, environmental conditions may not always be appropriate, and the conditions may cause stress for plants. Furthermore, unsuitable climate conditions and unfavorably rainfall distribution throughout the growing season are the main limitation on plant growth.

The stress factors can be biotic (bacteria, viruses, fungi, etc.) and abiotic (salinity, drought, low/high temperatures, nutrient deficiency/excess, etc.), causing serious effects in all life cycle stages of plants. Drought and salinity are the main dangerous stresses that threaten plant growth and production, and they have also been considered as one of the main factors determining the plant production destinies of countries for many years. Exposure to these stress factors trigger various physical, physiological, biochemical and molecular abnormalities in plants (Ashraf et al., 2002; Gong et al., 2005; Martinez et al., 2007; Sankar et al., 2008). Especially, there are two main processes that may be affected by stress conditions, namely photosynthesis and cell growth.

In the sense of plants growth and development, under stress conditions production of reactive oxygen species (ROS) are raised. Consequently increased ROS levels cause harm to the photosynthetic system and it can affect the performance (Chaves et al., 2009; Baghbani-Arani et al., 2017). On the other hand, under stress conditions plants show various stress mechanism to survive (Mirzaee et al., 2013; Nouraei et al., 2018).

Among environmental factors, light, water, and moisture are vital factors and have key roles in the physiological reactions, growth, and development of plants (Jagtap et al., 1998). Plants have the ability to regulate that their growth and development to optimizing their photosynthetic activity under unstable climate conditions (Hazrati et al., 2016). Photosynthesis, chlorophyll fluorescence, and carotenoid parameters may be affected by the above-stated factors (Maxwell and Johnson, 2000; Hazrati et al., 2016). 
Accumulating proline has been also determined in plants under adverse environmental conditions. Proline has many functional roles; an osmoprotectant, non-enzymatic antioxidant, scavenger of ROS, and protector of plant tissues, a source of carbon and nitrogen for plants (Smirnoff and Cumbes, 1989; Szabados and Savouré, 2010).

The present study, therefore, aimed to comparatively assess proline, chlorophyll ( $a$ and $b$ ), and carotenoid contents in leaves of Bayrampaşa OP and Sakız OP globe artichokes in young and mature leaves and growing seasons.

\section{MATERIALS and METHODS}

\section{Plant Material Experimental Condition and Sample Preparation}

Plants of Bayrampaşa OP and Sakız OP were grown in the experimental fields of Department of Horticulture, Faculty of Agriculture, Akdeniz University, while proline, chlorophyll and carotenoid analyses were conducted in the laboratory of Department of Chemistry, Faculty of Science, Akdeniz University, Antalya.

The soil texture characteristic of the experimental field is classified as clay soil. The experimental field's climate conditions are well-known with mild-wet winters and dry-hot summers, as characteristic of Mediterranean climate conditions. Data are given in Tables 1 and 2 related to soil and climate conditions, respectively.

The experiment was conducted with two globe artichoke cultivar's leaves. For this purpose eight to ten fresh leaves, young and mature, were separately collected from five different plants in three growing seasons (Autumn, Winter, Spring). Collected leaves were transferred to the laboratory and weighed immediately. Weighed leaves were kept at $65^{\circ} \mathrm{C}$, dried until they get the constant weight, separately ground, and then samples were stacked away at $-20^{\circ} \mathrm{C}$ until analyses.

Table 1. Soil characteristics of the experimental field.

\begin{tabular}{lr}
\hline Soil characteristics & \\
\hline Clay (\%) & 46.56 \\
Silt (\%) & 22.00 \\
Sand (\%) & 31.44 \\
Limestone (\%) & 42.90 \\
Organic matter (\%) & 5.93 \\
Conductivity (EC value) (mS/cm) & 469.1 \\
$\mathrm{pH}$ & 7.34 \\
\hline Mineral substances & \\
\hline $\mathrm{K}(\mathrm{ppm})$ & 681.43 \\
$\mathrm{Na}(\mathrm{ppm})$ & 56.18 \\
$\mathrm{Ca}(\mathrm{ppm})$ & 5465.16 \\
$\mathrm{Mg}(\mathrm{ppm})$ & 432.70 \\
\hline
\end{tabular}




\begin{tabular}{lr}
\hline $\mathrm{Fe}(\mathrm{ppm})$ & 7.72 \\
$\mathrm{Mn}(\mathrm{ppm})$ & 28.04 \\
$\mathrm{Cu}(\mathrm{ppm})$ & 1.36 \\
$\mathrm{Zn}(\mathrm{ppm})$ & 3.52 \\
\hline
\end{tabular}

Table 2. Climate conditions during the experimental growing season (Autumn, Winter, Spring) of the experimental field.

\begin{tabular}{lccccc}
\hline Growing Seasons & $\begin{array}{c}\text { Maximum } \\
\text { temperature } \\
\left({ }^{\circ} \mathbf{C}\right)\end{array}$ & $\begin{array}{c}\text { Minimum } \\
\text { temperature } \\
\left({ }^{\circ} \mathbf{C}\right)\end{array}$ & $\begin{array}{c}\text { Mean } \\
\text { temperature } \\
\left({ }^{\circ} \mathbf{C}\right)\end{array}$ & $\begin{array}{c}\text { Mean } \\
\text { precipitation } \\
(\mathbf{m m})(\text { in days) }\end{array}$ & $\begin{array}{c}\text { Mean } \\
\text { humidity } \\
(\boldsymbol{\%})\end{array}$ \\
\hline Autumn & 27.36 & 19.41 & 22.76 & $0.17(22$ days $)$ & 51.00 \\
Winter & 16.03 & 9.13 & 12.11 & $0.36(68$ days $)$ & 65.89 \\
Spring & 21.44 & 14.27 & 17.61 & $0.12(35$ days $)$ & 60.57 \\
\hline
\end{tabular}

\section{Proline content}

Determination of proline content of artichoke samples were carried out according to Carillo and Gibon (2011). Amount of $0.2 \mathrm{~g}$ dried and grinded artichoke was weighed in a screw cap tube and $10 \mathrm{~mL}$ ethanol:water mixture (70:30) added on to. The mixture was agitated for overnight with orbital shaker. Then the mixture centrifuged at $4000 \mathrm{rpm}$ for 15 minutes and supernatant was used for subsequent steps as an ethanolic extract.

Calibration curve was prepared at five different concentrations at the range of $0.2 \mathrm{mM}-5 \mathrm{mM}$. The reaction mix $(1 \%$ ninhydrin $(w / v)+60 \%$ acetic acid solution $(v / v)+20 \%(v / v)$ EtOH) was added to all samples and calibration curve points to complete reaction and give a yellow color.

For analysis, $500 \mu \mathrm{L}$ ethanolic extract (or $100 \mu \mathrm{L}$ proline standard $+400 \mu \mathrm{L}$ ethanol:water mixture (60:40)) and $1000 \mu \mathrm{L}$ reaction mix were transferred to $2 \mathrm{~mL}$ Eppendorf tube and heated at $95^{\circ} \mathrm{C}$ for 20 minutes in a water bath. Then sample was centrifuged at $10000 \mathrm{rpm}$ and following that adequate volume of sample transferred to micro UV cuvette for spectrophotometric analysis. The measurements were occurred at $520 \mathrm{~nm}$ at UV-VIS spectrophotometer.

\section{Chlorophyll a \& b, total carotenoid contents}

Prior to analysis artichoke samples were dried and milled $0.2 \mathrm{~g}$ artichoke sample was weighed into $15 \mathrm{~mL}$ screw cap tube, $10 \mathrm{~mL}$ methanol was added and the mixture was shaken for 4 hours. Then the sample centrifuged at $4000 \mathrm{rpm}$ for 10 minutes. The supernatant was transferred to UV cuvette and the absorbance was read at 400-700 nm with UV-VIS spectrophotometer. The amounts of chlorophyll a, chlorophyll b and total carotenoid were calculated by using Lichtentaler and Wellburn's (1983) formula. The absorbances at $666 \mathrm{~nm}, 653 \mathrm{~nm}, 470 \mathrm{~nm}$ were followed for determination of chlorophylls 
and total carotenoid. The calculation varies depending on the solvent used for extraction. The formulas for methanol are;

$$
\begin{aligned}
& \mathrm{Ca}=15.65 \text { A666 - 7.340 A653 } \\
& \mathrm{Cb}=27.05 \text { A653 - 11.21 A666 } \\
& \mathrm{Cx}+\mathrm{c}=1000 \mathrm{~A} 470-2.860 \mathrm{Ca}-129.2 \mathrm{Cb} / 245
\end{aligned}
$$

\section{Statistical analysis}

The experiment was carried out as three replications. Eight to ten fresh leaves were separately used for young and mature leaves, and five different plants were used in each replicate in three growing seasons (Autumn, Winter, Spring). The data obtained from the study were subjected to three-way ANOVA variance analyses with interaction using the SPSS program and the experiments were carried out with Duncan's multiple comparison test.

\section{RESULTS and DISCUSSION}

According to Table 2, the data belong to the experimental field, it was determined that the lowest mean temperature and the highest precipitation days were in winter. Besides temperature values, it is known that plant growth and development also depend on the amount of precipitation and rainy day periods (Pandino et al., 2015). Proline content of artichoke leaves was affected by the variation of climate conditions of growing seasons, cultivars, and leaf matureness (Table 3). According to obtained results, the proline content of young leaves of the Bayrampaşa OP cultivar was more prominent in autumn. It was assumed that it was due to high average temperature compared to other growing seasons, as well as the relatively lower average precipitation and humidity. It is known that the proline accumulation is increased under water stress conditions. Some researchers also found that the accumulation of proline was higher in leaves comparison to other plant parts. This situation could be related to plant parts growth and it is thought that the reason is the most rapidly growing plant parts the more being sensitive to the stress conditions (Nandwal et al., 1992; Nouraei et al., 2018). It is also known that Bayrampaşa plants are subjected to cold stress since they are grown in the northern part of the Aegean region under sub-optimal temperature conditions. Thus, it is thought that they may be more stress-tolerant than Sakız plants. 
Table 3. Proline contents of Bayrampaşa OP and Sakız OP cultivars

\begin{tabular}{|c|c|c|c|c|c|c|c|c|}
\hline \multirow{2}{*}{\multicolumn{2}{|c|}{$\begin{array}{l}\text { Cultivars } \\
\text { Growing Seasons }\end{array}$}} & \multicolumn{3}{|c|}{ Bayrampaşa OP } & \multicolumn{3}{|c|}{ Sakız OP } & \multirow{2}{*}{$\begin{array}{l}\text { Mean } \\
\text { values of } \\
\text { leaf } \\
\text { matureness }\end{array}$} \\
\hline & & Autumn & Winter & Spring & Autumn & Winter & Spring & \\
\hline \multirow{2}{*}{$\begin{array}{l}\text { Leaf } \\
\text { matureness }\end{array}$} & $\begin{array}{l}\text { Young } \\
\text { leaves }\end{array}$ & $2,48^{\mathrm{A}}$ & $1,77^{\mathrm{C}}$ & $0,76^{\mathrm{G}}$ & $1,19^{\mathrm{D}}$ & $2,07^{\mathrm{B}}$ & $0,30^{\mathrm{I}}$ & $1,43^{\mathrm{A}}$ \\
\hline & $\begin{array}{l}\text { Mature } \\
\text { leaves }\end{array}$ & $1,16^{\mathrm{E}}$ & $0,80^{\mathrm{F}}$ & $0,71^{\mathrm{H}}$ & $0,72^{\mathrm{H}}$ & $1,17^{\mathrm{E}}$ & $0,24^{\mathrm{J}}$ & $0,80^{\mathrm{B}}$ \\
\hline \multicolumn{2}{|c|}{$\begin{array}{l}\text { Mean values of } \\
\text { cultivars }\end{array}$} & & $1,28^{\mathrm{A}}$ & & & $0,95^{\mathrm{B}}$ & & \\
\hline
\end{tabular}

With regards to chlorophyll $\mathrm{a}$ and $\mathrm{b}$ contents, it was found that there were statistical significant differences among cultivars, leaf matureness, and growing seasons. According to this, the accumulation of chlorophyll a was found to be high in the young leaves of Bayrampaşa OP in winter, while chlorophyll $\mathrm{b}$ accumulation was higher in the mature leaves of Sakız OP in autumn growing season (Tables 4 and 5). For determining the density of photosynthesis, it was reported that the concentration of chlorophyll was one of the main determinants (Ghosh et al., 2004; Baghbani-Arani et al., 2017). It is known that the concentration of chlorophyll is decreased under stressful environmental conditions (Ranjbar Fordoei and Dehghani Bidgholi, 2016; Baghbani-Arani et al., 2017).

Table 4. Chlorophyll a contents of Bayrampaşa OP and Sakız OP cultivars

\begin{tabular}{|c|c|c|c|c|c|c|c|c|}
\hline \multicolumn{2}{|l|}{ Cultivars } & \multicolumn{3}{|c|}{ Bayrampaşa OP } & \multicolumn{3}{|c|}{ Sakız OP } & $\begin{array}{l}\text { Mean } \\
\text { values of } \\
\text { leaf } \\
\text { matureness }\end{array}$ \\
\hline Growing Se: & ons & Autumn & Winter & Spring & Autumn & Winter & Spring & \\
\hline \multirow{2}{*}{$\begin{array}{l}\text { Leaf } \\
\text { matureness }\end{array}$} & $\begin{array}{l}\text { Young } \\
\text { leaves }\end{array}$ & $189,85^{\mathrm{J}}$ & $12487,75^{\mathrm{A}}$ & $3686,74^{\mathrm{C}}$ & $87,09^{\mathrm{K}}$ & $2665,22^{\mathrm{H}}$ & $2745,80^{\mathrm{G}}$ & $3643,74^{\mathrm{A}}$ \\
\hline & $\begin{array}{l}\text { Mature } \\
\text { leaves }\end{array}$ & $3244,92^{\mathrm{D}}$ & $2620,27^{\mathrm{H}}$ & $5512,99^{\mathrm{B}}$ & $3015,71^{\mathrm{E}}$ & $2957,91^{\mathrm{F}}$ & $1938,48^{\mathrm{I}}$ & $3215,04^{\mathrm{B}}$ \\
\hline \multicolumn{2}{|c|}{$\begin{array}{l}\text { Mean values of } \\
\text { cultivars }\end{array}$} & & $4623,75^{\mathrm{A}}$ & & & $2235,03^{\mathrm{B}}$ & & \\
\hline
\end{tabular}

Table 5. Chlorophyll b contents of Bayrampaşa OP and Sakız OP cultivars

\begin{tabular}{|c|c|c|c|c|c|c|c|c|}
\hline \multirow{2}{*}{\multicolumn{2}{|c|}{$\begin{array}{l}\text { Cultivars } \\
\text { Growing Seasons }\end{array}$}} & \multicolumn{3}{|c|}{ Bayrampaşa OP } & \multicolumn{3}{|c|}{ Sakız OP } & \multirow{2}{*}{$\begin{array}{l}\text { Mean } \\
\text { values of } \\
\text { leaf } \\
\text { matureness }\end{array}$} \\
\hline & & Autumn & Winter & Spring & Autumn & Winter & Spring & \\
\hline \multirow{2}{*}{$\begin{array}{l}\text { Leaf } \\
\text { matureness }\end{array}$} & $\begin{array}{l}\text { Young } \\
\text { leaves }\end{array}$ & $6,06^{\mathrm{J}}$ & $17,63^{\mathrm{D}}$ & $14,17^{\mathrm{F}}$ & $26,53^{\mathrm{C}}$ & $7,17^{\mathrm{I}}$ & $5,21^{\mathrm{K}}$ & $12,79^{\mathrm{B}}$ \\
\hline & $\begin{array}{l}\text { Mature } \\
\text { leaves }\end{array}$ & $9,53^{\mathrm{H}}$ & $7,19^{\mathrm{I}}$ & $10,73^{\mathrm{G}}$ & $42,91^{\mathrm{A}}$ & $40,95^{\mathrm{B}}$ & $16,33^{\mathrm{E}}$ & $21,27^{\mathrm{A}}$ \\
\hline \multicolumn{2}{|c|}{ Mean values of cultivars } & & $10,88^{\mathrm{B}}$ & & & $23,18^{\mathrm{A}}$ & & \\
\hline
\end{tabular}

Different letters in the same column and rows indicate a statistically significant difference at $\mathrm{P} \leq 0.05$. 
Results also revealed that there were statistically significant differences among cultivars, leaf matureness, and growing seasons regarding carotenoid contents (Table 6). In the present study, the highest concentration of carotenoid was determined in mature leaves of Sakiz OP cultivar in winter growing season. Carotenoid accumulation under stress conditions shows differences in respect to plants, and it could play a role on protection from oxidative stress damages (Mir-Aafaq et al., 2013). Some researchers reported that the leaves carotenoid contents increased (Kadkhodaie et al., 2014), while some others noted the reduction (Maroco et al., 2002) under stress conditions in different plants (Nouraei et al., 2018).

Table 6. Carotenoid contents of Bayrampaşa OP and Sakız OP cultivars

\begin{tabular}{|c|c|c|c|c|c|c|c|c|}
\hline \multirow{2}{*}{\multicolumn{2}{|c|}{$\begin{array}{l}\text { Cultivars } \\
\text { Growing Seasons }\end{array}$}} & \multicolumn{3}{|c|}{ Bayrampaşa OP } & \multicolumn{3}{|c|}{ Sakız OP } & \multirow{2}{*}{$\begin{array}{l}\text { Mean values } \\
\text { of leaf } \\
\text { matureness }\end{array}$} \\
\hline & & Autumn & Winter & Spring & Autumn & Winter & Spring & \\
\hline \multirow{2}{*}{$\begin{array}{l}\text { Leaf } \\
\text { matureness }\end{array}$} & $\begin{array}{l}\text { Young } \\
\text { leaves }\end{array}$ & $24,85^{\mathrm{J}}$ & $40,80^{\mathrm{F}}$ & $52,77^{\mathrm{E}}$ & $67,46^{\mathrm{C}}$ & $24,04^{\mathrm{K}}$ & $24,10^{\mathrm{K}}$ & $39,00^{\mathrm{B}}$ \\
\hline & $\begin{array}{l}\text { Mature } \\
\text { leaves }\end{array}$ & $36,93^{\mathrm{H}}$ & $30,13^{\mathrm{I}}$ & $38,66^{\mathrm{G}}$ & $94,24^{\mathrm{B}}$ & $96,33^{\mathrm{A}}$ & $63,00^{\mathrm{D}}$ & $59,88^{\mathrm{A}}$ \\
\hline \multicolumn{2}{|c|}{$\begin{array}{l}\text { Mean values of } \\
\text { cultivars }\end{array}$} & & $37,35^{\mathrm{B}}$ & & & $61,53^{\mathrm{A}}$ & & \\
\hline
\end{tabular}

\section{Conclusion}

The findings of the present study revealed that the accumulation of proline, chlorophyll $a$ and $b$, and carotenoid in the two OP globe artichokes showed differences in accordance with cultivar, leaf matureness and growing seasons. Young leaves and Bayrampaşa OP was more promising in terms of proline and chlorophyll a content, while mature leaves and Sakız OP were prominent in terms of chlorophyll $\mathrm{b}$ and carotenoid contents. When considering globe artichoke proline and photosynthetic pigments regardless of cultivars and leaf matureness, it should be taken into account that autumn and winter have more potential than spring. Considering that there are many local globe artichoke cultivars in Turkey, similar studies should be carried out to reveal their valuable potential under stress conditions.

\section{Acknowledgement}

The present study was partly funded by Akdeniz University Scientific Research Projects Coordination Unit with the project numbers FDK-2019-4611 and FBA-2019-4814.

We would like to thank Dr. Ebru Kaya Basar for her kind support during statistical analysis in this research.

\section{REFERENCES}

Ahmad, M. A., Murali, P. V., \& Panneerselvam, R. (2013). Drought stress induced biochemical alterations in two varieties of Paspalum scrobiculatum L. International Journal of Current Science, (7), 80-96. 
Ashraf, M., Arfan, M., Shahbaz, M., Ahmad, A., \& Jamil, A. (2002). Gas exchange characteristics and water relations in some elite okra cultivars under water deficit. Photosynthetica, 40(4), 615-620.

Baghbani-Arani, A., Modarres-Sanavy, S. A. M., Mashhadi-Akbar-Boojar, M., \& Mokhtassi-Bidgoli, A. (2017). Towards improving the agronomic performance, chlorophyll fluorescence parameters and pigments in fenugreek using zeolite and vermicompost under deficit water stress. Industrial Crops and Products, 109, 346-357.

Carillo, P., \& Gibon, Y. (2011). Protocol: extraction and determination of proline. PrometheusWiki.

Chaves, M. M. (2009). Flexas., Pinheiro C. Photosynthesis under drought and salt stress: regulation mechanisms from whole plant to cell. Ann. Bot, 103, 551-560.

Fratianni, F., Tucci, M., De Palma, M., Pepe, R., \& Nazzaro, F. (2007). Polyphenolic composition in different parts of some cultivars of globe artichoke (Cynara cardunculus L. var. scolymus (L.) Fiori). Food chemistry, 104(3), 1282-1286.

Gebhardt, R. (2001). Anticholestatic activity of flavonoids from artichoke (Cynara scolymus L.) and of their metabolites. Medical science monitor: international medical journal of experimental and clinical research, 7, 316-320.

Ghosh, P. K., Ramesh, P., Bandyopadhyay, K. K., Tripathi, A. K., Hati, K. M., Misra, A. K., \& Acharya, C. L. (2004). Comparative effectiveness of cattle manure, poultry manure, phosphocompost and fertilizer-NPK on three cropping systems in vertisols of semi-arid tropics. I. Crop yields and system performance. Bioresource technology, 95(1), 77-83.

Gong, H., Zhu, X., Chen, K., Wang, S., \& Zhang, C. (2005). Silicon alleviates oxidative damage of wheat plants in pots under drought. Plant science, 169(2), 313-321.

Hazrati, S., Tahmasebi-Sarvestani, Z., Modarres-Sanavy, S. A. M., Mokhtassi-Bidgoli, A., \& Nicola, S. (2016). Effects of water stress and light intensity on chlorophyll fluorescence parameters and pigments of Aloe vera L. Plant Physiology and Biochemistry, 106, 141-148.

Kadkhodaie, A., Zahedi, M., Razmjoo, J., \& Pessarakli, M. (2014). Changes in some anti-oxidative enzymes and physiological indices among sesame genotypes (Sesamum indicum L.) in response to soil water deficits under field conditions. Acta Physiologiae Plantarum, 36(3), 641-650.

Lattanzio, V., Kroon, P. A., Linsalata, V., \& Cardinali, A. (2009). Globe artichoke: A functional food and source of nutraceutical ingredients. Journal of functional foods, 1(2), 131-144.

Lichtenthaler, H. K., \& Wellburn, A. R. (1983). Determinations of total carotenoids and chlorophylls a and $\mathrm{b}$ of leaf extracts in different solvents. Biochemical Society Transactions $603^{\text {rd }}$ Meeting, vol 11. Liverpool 591-592.

Lombardo, S., Pandino, G., Mauromicale, G., Knödler, M., Carle, R., \& Schieber, A. (2010). Influence of genotype, harvest time and plant part on polyphenolic composition of globe artichoke [Cynara cardunculus L. var. scolymus (L.) Fiori]. Food Chemistry, 119(3), 1175-1181.

Maroco, J. P., Rodrigues, M. L., Lopes, C., \& Chaves, M. M. (2002). Limitations to leaf photosynthesis in field-grown grapevine under drought-metabolic and modelling approaches. Functional Plant Biology, 29(4), 451-459.

Martínez, J. P., Silva, H. F. L. J., Ledent, J. F., \& Pinto, M. (2007). Effect of drought stress on the osmotic adjustment, cell wall elasticity and cell volume of six cultivars of common beans (Phaseolus vulgaris L.). European journal of agronomy, 26(1), 30-38. 
Maxwell, K., \& Johnson, G. N. (2000). Chlorophyll fluorescence-a practical guide. Journal of experimental botany, 51(345), 659-668.

Mirzai, M., Moeini, A., \& Ghanati, F. (2013). Effects of drought stress on the lipid peroxidation and antioxidant enzyme activities in two canola (Brassica napus L.) cultivars. J. Agric. Sci. Technol. 15, 593-602.

Nandwal, A. S., Bharti, S., \& Singh, I. (1992). Assimilate partitioning in pigeonpea under two levels of drought and during recovery. Biologia plantarum, 34(3), 267-273.

Nouraei, S., Rahimmalek, M., \& Saeidi, G. (2018). Variation in polyphenolic composition, antioxidants and physiological characteristics of globe artichoke (Cynara cardunculus var. scolymus Hayek L.) as affected by drought stress. Scientia Horticulturae, 233, 378-385.

Pandino, G., Lombardo, S., \& Mauromicale, G. (2013). Globe artichoke leaves and floral stems as a source of bioactive compounds. Industrial Crops and Products, 44, 44-49.

Pandino, G., Lombardo, S., Moglia, A., Portis, E., Lanteri, S., \& Mauromicale, G. (2015). Leaf polyphenol profile and SSR-based fingerprinting of new segregant Cynara cardunculus genotypes. Frontiers in plant science, 5,800 .

Ranjbar, F. A., \& Dehghani, B. R. (2016). Impact of salinity stress on photochemical efficiency of photosystem ii, chlorophyll content and nutrient elements of nitere bush (Nitraria schoberi L.) Plants. Journal of Rangeland Science, 6(1).

Romani, A., Pinelli, P., Cantini, C., Cimato, A., \& Heimler, D. (2006). Characterization of Violetto di Toscana, a typical Italian variety of artichoke (Cynara scolymus L.). Food Chemistry, 95(2), 221-225.

Ruiz-Aceituno, L., García-Sarrió, M. J., Alonso-Rodriguez, B., Ramos, L., \& Sanz, M. L. (2016). Extraction of bioactive carbohydrates from artichoke (Cynara scolymus L.) external bracts using microwave assisted extraction and pressurized liquid extraction. Food chemistry, 196, 1156-1162.

Sankar, B., Jaleel, C. A., Manivannan, P., Kishorekumar, A., Somasundaram, R., \& Panneerselvam, R. (2008). Relative efficacy of water use in five varieties of Abelmoschus esculentus (L.) Moench. under water-limited conditions. Colloids and Surfaces B: Biointerfaces, 62(1), 125-129.

Siadat-Jamian, S., Aghaalikhani, M., Soufizadeh, S., \& Mokhtassi-Bidgoli, A. (2019). Qualitative and quantitative response of artichoke to irrigation treatments and planting densities. Scientia Horticulturae, 253, 422-428.

Smirnoff, N., \& Cumbes, Q. J. (1989). Hydroxyl radical scavenging activity of compatible solutes. Phytochemistry, 28(4), 1057-1060.

Szabados, L., \& Savouré, A. (2010). Proline: a multifunctional amino acid. Trends in plant science, 15(2), 89-97.

Vamanu, E., Vamanu, A., Nita, S., \& Colceriu, S. (2011). Antioxidant and antimicrobial activities of ethanol extracts of Cynara scolymus (Cynarae folium, Asteraceae family). Tropical Journal of Pharmaceutical Research, 10(6), 777-783. 